\title{
Scale Up Sediment Microbial Fuel Cell For Powering Led Lighting
}

\author{
Jeetendra Prasad*, Ramesh Kumar Tripathi \\ Department of Electrical Engineering Motilal Nehru National Institute of Technology \\ Allahabad, Uttar Pradesh 211004, India
}

\begin{abstract}
Sediment microbial fuel cells (SMFCs) are expected to be utilized as a sustainable power source for remote environmental observing 30 day's investigations of experiment to understand the long-term performance of SMFCs. The point of this investigation is to increase power generation, 8 individual sediment microbial fuel cells is stacked together either in series or in hybrid connection. Two combinations, of the hybrid connection, are proving to be the more effective one, step-up both the voltage and current of the framework, mutually. Polarization curve tests are done for series and hybrid connected sediment microbial fuel cell. The maximum study state voltage and current are obtained $8.150 \mathrm{~V}$ and $435.25 \mu \mathrm{A}$ from series and $4.078 \mathrm{~V}$ and $870.75 \mu \mathrm{A}$ hybrid connected SMFC. This study suggests that power of SMFC scale-up by connecting series and hybrid for practical use of the device.
\end{abstract}

Keywords: sediment microbial fuel cell, series, hybrid connection, open circuit voltage, Power source

Article History: Received : September 26 ${ }^{\text {th }}$ 2017; Received: December 24 ${ }^{\text {th }}$ 2017; Accepted: Januari $4^{\text {th }} 2018$; Available online How to Cite This Article: Prasad, J and Tripathi, R.K. (2018) Scale Up Sediment Microbial Fuel Cell For Powering Led Lighting. International Journal of Renewable Energy Development, 7(1), 53-58.

https://doi.org/10.14710/ijred.7.1.53-58

\section{Introduction}

Presently, expanding world population and expanding welfare, energy request worldwide is growing. Right now, jumble-sale of fossil fuels is unevenly appropriated over the world is being depleted, and is unsustainable. Sustainable renewable energy sources are accessible these days all have their disadvantages. They are climate subordinate (wind, solar power), contend with food/feed generation (some biofuels) or include high speculation costs. The present environmental change by $\mathrm{CO}_{2}$ production from burning of fossil fuels raises the resolution for renewable energy invention. Presently many researchers are working on various sustainable power sources such as solar energy, wind and geothermal (Panwar et al., 2011). But every one of these sources cannot be utilized in areas that don't have particular geological elements. Therefore, new innovations should be created to block this gap. Fuel cell innovation is a standout amongst the most encouraging lines since it proposes a one of a kind combination of advantages that make it a crucial innovation. Fuel cell is in a perfect world suited for extensive market fragments of our vitality framework without any pollution, have the high efficiency conversion of biochemical energy to electricity (Kreuer 2013). Over the previous decade, the progress of the microbial fuel cell (MFC) in biotechnological study offers a brand new innovation that turns biochemical energy of biological matter into electricity using micro-organisms as the substance (Aelterman et al., 2006, Lemuel et al., 1982, Reimers et al., 2001, Kim et al., 2002, Gil et al., 2003).

Sediment microbial fuel cells (SMFCs) are expected to be utilized as a sustainable power source to activate remote sensors and electrical equipment for environmental observing (Dewan et al., 2014). Soil of lakes, rivers, and oceans used as electrolyte and generate power where needed without maintenance (Donovan et al., 2008, Tender et al., 2008, Reimer et al., 2001). The main advantages of SMFCs are that they do not generate toxic wastes, tiny maintenance necessity, long-term energy generation as well as in situ waste water treatment, while the batteries generally utilized for this reason are not relevant for a long time (Donovan et al., 2013, Zho et al., 2014, Ewing et al., 2014).

The organic compounds in the sediment serve promising renewable fuel of electro- organic microbes

\footnotetext{
*Corresponding author: enjeetendra@gmail.com
} 
to inoculate the anode surface. Electro-genic microbes involve Geobacter sulfurreducens (Wang et al., 2014, Bond et al., 2003), Rhodoferax ferrireducens (Jiang et al., 2010), Shewanella putrefaciens (Chaudhuri et al., 2003), Clostridium spp. (Kim et al., 1999), and Bradyrhizobium spp., which oxidize organic matter and generate electrons and protons (Rismani-Yazdi et al., 2007, Zhang et al., 2012, Aller 1994). Open circuit red-ox potential Between the sediment and overlaying water is $0.7 \mathrm{~V}$ to $0.8 \mathrm{~V}$ (Reimers et al., 2006). These electrons are moved from anode to cathode via an external circuit and accepted by an electron acceptor in the cathode, where they condense oxygen (Ateya et al., 2002). Single-chamber SMFC has just an anode while the cathode is presented to the air, with electron acceptor $\mathrm{O}_{2}$.

Table 1

Performance studies of different anode cathode used in Sediment MFC

\begin{tabular}{llll}
\hline Anode & Cathode & Open circuit voltage (V) & Reference \\
\hline Graphite anode & Carbon fibre & 0.400 & (Wotawa et al., 2010) \\
Graphite fibre & Graphite fibre & 0.664 & (Xu et al., 2017) \\
Carbon felt & Carbon felt & 0.158 & (Abazarian et al., 2016) \\
Graphite felt & Iron & 0.431 & (Zhang et al., 2015) \\
Iron & Graphite felt & 0.645 & (Zhang et al., 2015) \\
Carbon cloth & Carbon cloth & 0.250 & (Majumder et al., 2014) \\
copper & zinc & 1.160 & [This work] \\
\hline
\end{tabular}

Microbial fuel cell can be a stacked configuration either in the form of series connection or in parallel connection (IoannisIeropoulos et al., 2008). The voltage of the MFC in series connection is the sum of the Single MFC voltages and the current of the MFC stack in parallel configuration is the sum of the single MFC currents and the voltage is the average voltage of all the MFCs in the stack (Peter Aelterman et al., 2006, IoannisIeropoulos et al., 2010).

In an effort to increase power from MFCs, eight MFCs stacked in series electrically connected by copper wires. The stacked configuration enabled an increase in the total voltage to $2.02 \mathrm{~V}$ (Peter Aelterman et al., 2006). In another MFC study, a double-cell air-cathode MFC stack verified and found that the stacked MFC developed an operational

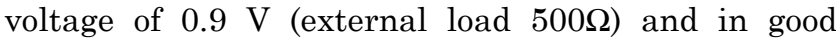
condition, the MFC had an open circuit voltage (OCV) of $1.3 \mathrm{~V}$ (Oh et al.,2007). Performance studies of different anode and cathode used in Sediment MFC Type have been summarized in Table1. They developed the different voltage using different anode and cathode material. In this research work, development of a Sediment MFC is using copper anode and zinc cathode has been done. It has been observed that this generates higher voltage in comparison to the previous reported researcher. In this study, the power output from sediment substrates was examined $8.15 \mathrm{~V}$ by series connected SMFCs using zinc as an anode and copper as a cathode. The spacing between the anode and the cathode was kept as minimum as possible. In order to increase power generation, SMFCs were stacked together in series and in parallel. Additionally, the stack MFC was operated in batch mode for 30 days in series.

\section{Materials and Methods}

\subsection{Raw Materials}

Electrolyte material consisting of sediment collected from flower field of Motilal Nehru National Institute of Technology (MNNIT), Allahabad, U.P, India was used as electrolyte. The sediment was kept at room temperature $\left(25^{\circ} \mathrm{C}\right)$ prior to experiment. This experiment tested in electrical laboratory of MNNIT, Allahabad, U.P,India.

\subsection{Sediment Microbial Fuel Cell assembly}

We designed Single chamber SMFC systems of volume $8 \mathrm{~L}$. The stacked SMFC 1 module was prepared by 8 individual SMFC units (Figure 1). Each individual SMFC unit had cylindrical poly-acrylic plastic shape of volume $\sim 1000 \mathrm{~mL}(8.89 \mathrm{~cm}$ width $\mathrm{x} 16.51 \mathrm{~cm}$ height). Half of the bottles were filled with sediment and other half were filled with water. An anode of Copper electrode $(7.5 \mathrm{~cm}$ height, $2.5 \mathrm{~cm}$ width and $2 \mathrm{~mm}$ thickness) was inserted into the cylindrical anode compartment. A cathode of Zinc electrode (7.5 $\mathrm{cm}$ height, $2.5 \mathrm{~cm}$ width and $2 \mathrm{~mm}$ thickness) was inserted into the cylindrical cathode compartment. The Copper anode is set into sediment and zinc cathode is suspended in the water section. The distance between electrodes kept $2 \mathrm{~cm}$. The electrode was connected by copper wire $\left(1.5 \mathrm{~mm}^{2}\right)$ through the external load. The inoculated cultures were incubated 
at room temperature $25^{\circ} \mathrm{C}$. The microscopic organisms were completely developed for the term of $24 \mathrm{~h}$ in sediment with no unsettling. For the series connection of 8 SMFC units, the cathodes of SMFCs1 were connected to the anode from SMFCs2 up to final SMFC units (Figure1a). For the hybrid connection, 2 units connected in parallel; each unit contains 4 SMFC which was connected in series (Figure1b).

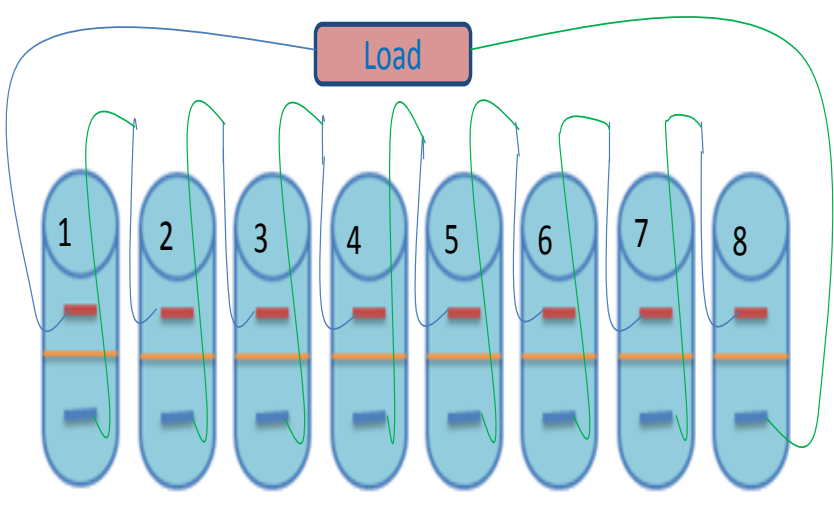

(a)

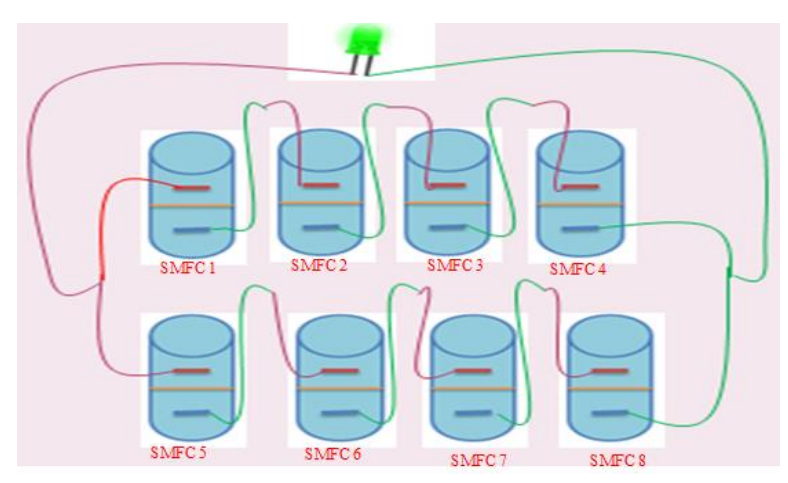

(b)

Fig. 1 SMFC Array connections. (a) Series (b) Hybrid

Table 2

The maximum study state voltage and current generated from different configuration

\begin{tabular}{lcc}
\hline $\begin{array}{l}\text { Type of } \\
\text { configuration }\end{array}$ & $\begin{array}{c}\text { Open circuit } \\
\text { voltage(V) }\end{array}$ & $\begin{array}{l}\text { Maximum } \\
\text { generated } \\
\text { current }(\boldsymbol{\mu A})\end{array}$ \\
\hline Series Connection & $8.150 \pm 1.031$ & $435.25 \pm 20$ \\
Hybrid Connection & $4.078 \pm 0.980$ & $870.75 \pm 50$ \\
\hline
\end{tabular}

\subsection{Experimental method and analysis}

About 600 gram of sediments was poured into the cylindrical plastic bottles for making all SMFC. This was then fixed with a plastic cap to recreate anaerobic condition anaerobic condition. The voltage and current were measured for the charged MFC using two digital multimeters (Agilent U1232A) at a specific time. The power output was checked by measuring voltage and current the outer resistor associated with the anode. Keeping in mind the end goal to acquire the polarization bend, the outer resistance was shifted from $47 \Omega$ to $147 \Omega$, to $214 \Omega$, to $327 \Omega$, to $475 \Omega$, to $687 \Omega$, to $735 \Omega$, to $835 \Omega$ and $987 \Omega$. The meter was associated with the framework through cathode terminals of the particular cathode and anode.

The voltage $\left(\mathrm{V}_{\mathrm{O}}\right)$ and current $\left(\mathrm{I}_{\mathrm{o}}\right)$ through different resistance (Ro) of the MFC measured every 60 second interval by two digital multi-meters. Where, the voltage $\mathrm{V}_{\mathrm{o}}$ (in $\mathrm{V}$ ), the current Io (in $\mu \mathrm{A}$ ) and outside resistance $R_{0}(\Omega)$. Power $\left(\mathrm{P}_{0}\right)$ was computed by $\mathrm{P}_{\mathrm{o}}=$ $\mathrm{I}_{0}$. $\mathrm{V}_{\mathrm{o}}$, Where $\mathrm{P}_{\mathrm{o}}$ is in $\mu \mathrm{W}$. The projected anode area was $0.339 \mathrm{~m}^{2}$.

The Coulombic efficiency (CE) is determined as the coulombs recovered by way of current $\left(\mathrm{CE}_{\mathrm{e}}\right)$ versus the theoretical amount available in organic matter $\left(\mathrm{CE}_{\mathrm{t}}\right)$, was calculated by integrating the current over time for an each interval of time as

$$
C E=\frac{C E_{e}}{C E_{t}} \times 100
$$

$$
\text { Where } \quad \mathrm{CE}_{\mathrm{e}}=\sum_{x=0}^{t} \frac{V_{x} \cdot I_{x}}{R}
$$

The theoretical value of coulombs that is available from $\operatorname{COD}(i=c)$ or propionate $(i=p)$ oxidation was determined as

$$
\mathrm{CE}_{t}=\frac{b_{x} S_{x} F v}{M_{x}}
$$

Where $\mathrm{F}$ is faraday's constant (96,485 C/mol.e-), $\mathrm{b}=4$ mole e-/mol.o2, $\mathrm{v}=1 \mathrm{~L}$ is total SMFC volume and $\mathrm{M}=32 \mathrm{~g} / \mathrm{mol}$ is molecular weight of oxygen.

\section{Experimental results and discussion}

\subsection{SMFC Start- up and Operation}

Microorganism in the Sediment microbial fuel cells requires an adaptation process and need a period of time for creation of the biofilm on the surface of the anode. Therefore, anaerobic fluidized bed microbial fuel cells startup require some time. Copper has standard potential (Eo) value higher than Zinc with $+0.337 \mathrm{~V}$ and $-0.763 \mathrm{~V}$ respectively. It means that Copper and zinc Electrode material generated maximum electrical energy and potential. At the beginning of startup, OCV of single SMFC was 1.160, $0.931,1.009,0.982,0.945,1.029,1.090$ and $1.010 \mathrm{~V}$, respectively. After 18 days, the maximum open circuit voltage of SMFCs was1.140, 0.920, 1.009, 0.981, 0.941, 1.029, 1.090 and 1.010V appeared, and OCV of SMFCs was same for 30 days (Figure 2). Different voltages were obtained in each Individual SMFC units indicating that into to the two systems were generated different oxidation-reduction reaction rates and difference in potential on the electrode due to the 
decreased the COD concentrations in each SMFC. Voltage of SMFC configuration is stable after 18 days.

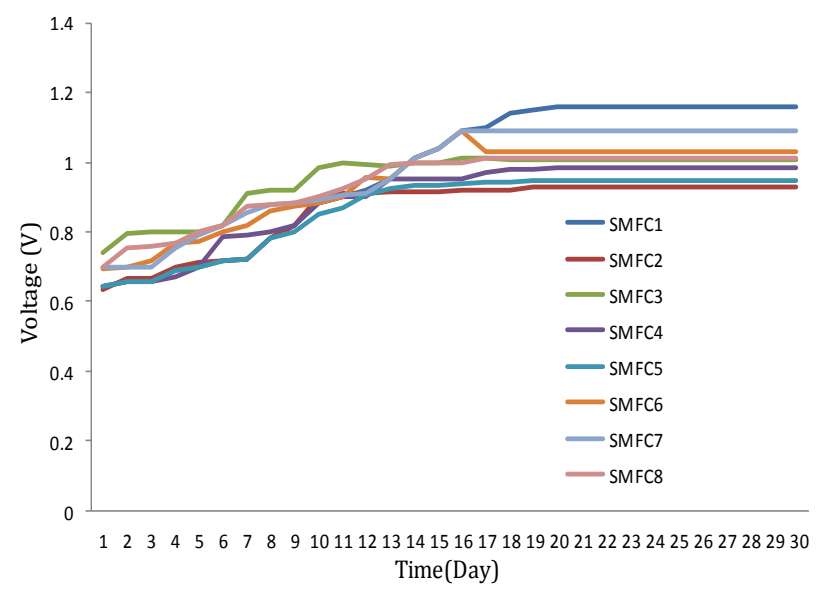

Fig. 2 Voltage generated by eight individual SMFCs

In order to increase power generation, all individual SMFCs were connected together either in series or in hybrid. The anode of the SMFC 1 is connected to the Cathode of SMFC 2 in order to complete the stackable series circuit. The stack circuit was performed when the SMFCs were in good working condition. When all SMFCs were stacked mutually in series, the OCV of the stacked series SMFCs equaled the mathematical addition of the separate SMFCs, which verified the fruitful series assembly. The stackable MFC configuration resulted in an OCV of $5.39 \mathrm{~V}$ of first day and OCV of $8.15 \mathrm{~V}$ after 20 days for the series connection. Steady state maximum short circuit current $435.25 \mu \mathrm{A}$ was obtained in series configuration.

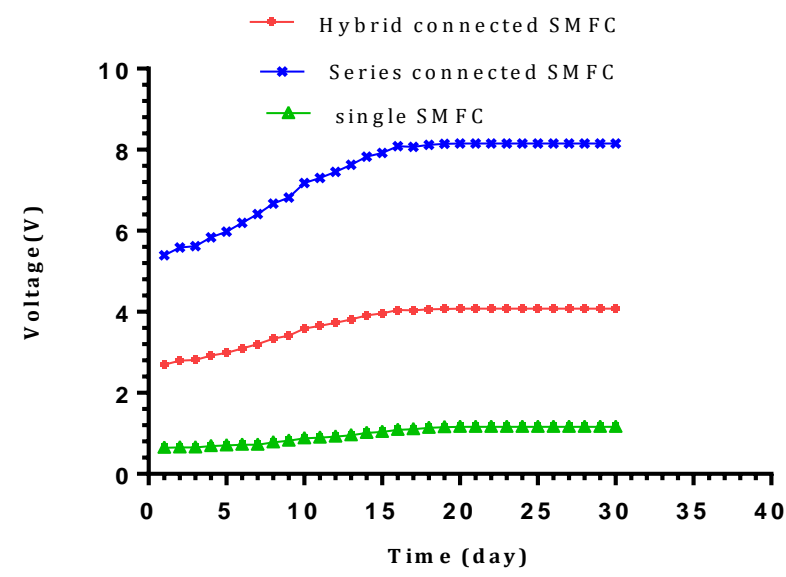

Fig. 3 Voltage generated by series connected and hybrid Connected SMFCs

Figure 3 shows the output voltages obtained during the stacked SMFC systems operation in series and hybrid connection respectively. This is a decent result in terms of potential for SMFC technology to power electronic devices. The individual SMFCs voltage is too low to be able to turn on a device so such configuration provides a level of voltage to turn on device. LED was glowing lighter in series configuration and brighter in hybrid configuration. This is due to the increase of the current level in hybrid- connection.

In hybrid connection, first day maximum open circuit voltage $2.69 \mathrm{~V}$ was obtained and voltage was continuous increasing. After 18 day voltage reach steady state voltage of $4.078 \mathrm{~V}$ and maximum short circuit current $870.75 \mu \mathrm{A}$ was obtained. Experiments showed that the hybrid SMFC configuration resulted in an increase the voltage as well as current.

\subsection{Polarization curves for series connection and hybrid connection}

The performance of SMFCs configuration was further inspected by polarization curves sweeping through changed resistances ( $47 \Omega$ to $987 \Omega$ ). Voltage and current was observed by varying different resistance. Figure 4 shows the polarization curves of Series connected SMFCs. Voltage showed decreasing trend with increasing in current and power first increases then decreases, which indicated a typical fuel cell behavior. The hybrid Configuration shows this trend, but at a lower power. The SMFCs were then stacked in series and the polarization curve was measured. The maximum power produced from Series connected SMFCs was $780.24 \mu \mathrm{W}$ corresponding to current of $199.80 \mu \mathrm{A}$. For the series configuration, the voltage is higher, starting at approximately 8 times the individual $\mathrm{MFC}$ at $7.57 \mathrm{~V}$ at $21.72 \mu \mathrm{A}$ and decreased to $1.03 \mathrm{mV}$ at $66.51 \mu \mathrm{A}$ by increasing load.

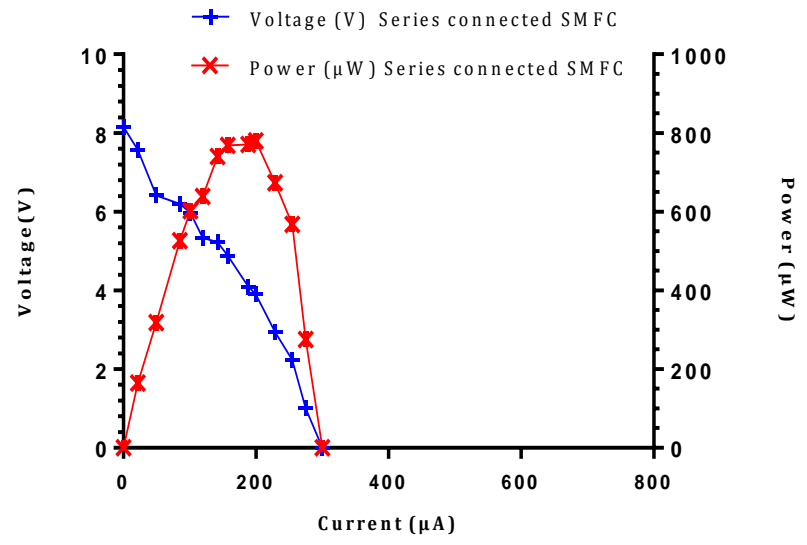

Fig. 4 Polarization Curve for series connected SMFCs

Figure 5 shows the polarization curve for the hybrid connection. The hybrid connection show lesser voltage and power developed by SMFC as compare to series configuration. But current profile is increased. By default, when the SMFCs were connected in hybrid, the voltage and current was increase. The maximum power of $486.84 \mu \mathrm{W}$ was obtained, corresponding to the maximum current of $350.50 \mu \mathrm{A}$. In the hybrid connection, the voltage starts at $3.40 \mathrm{~V}$ at $21.98 \mu \mathrm{A}$ and decreased to $0.60 \mathrm{~V}$ at $567.3 \mu \mathrm{A}$ which is 
approximately 2 times the current output of an individual SMFC. The stack performances were performed successfully without any voltage reversals. Power achieved in this experiment was comparable more with the previous MFC studies with acetate as substrate (Liu et al., 2004).

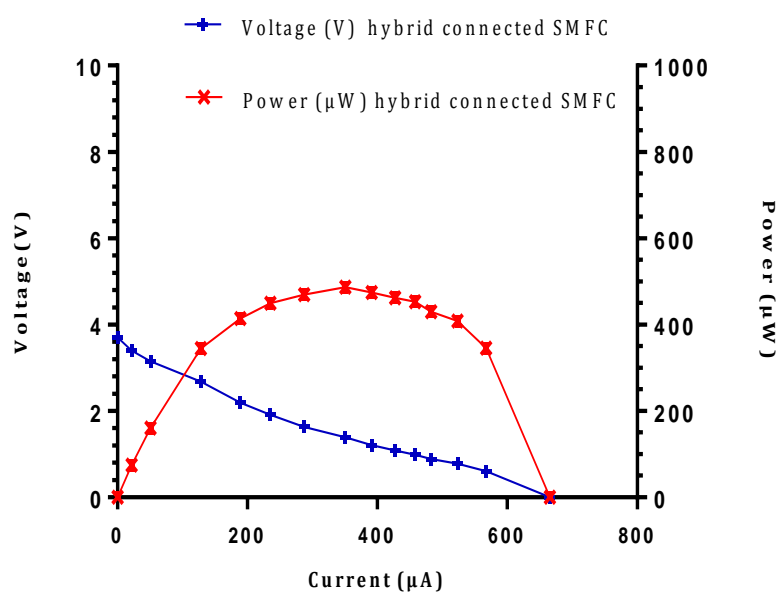

Fig.5 Polarization Curve for hybrid connected SMFCs

Our result indicates the potential to power implanted sediment microbial fuel cell using bacteria. In each of configuration, the power is sufficient to operate devices. Based on this connection of sediment microbial fuel cell, we altogether enhanced the power generation of the SMFCs unit and potentially established a general design platform for a scalable biological fuel cell. In future work power can improve by using dc to dc boost converter.

\subsection{Columbic efficiency}

Coulombic efficiency (CE) determined how proficiently an MFC harvests electrons. The SMFC was filled with the wastewater COD concentration of $192 \mathrm{mg} / \mathrm{L}$ and sediment anode compartment had $\mathrm{pH}$ value of 7.4. CE calculated of 8 SMFC by equation (1) were $28.20 \%$, $26.01 \%, 27.62 \%, 26.90 \%, 26.50 \%, 27.91 \%, 27.69 \%$ and $27.70 \%$ for SMFC1, SMFC2, SMFC3, SMFC4, SMFC5, SMFC6, SMFC7 and SMFC8 respectively. The average $\mathrm{CE}$ of all $8 \mathrm{SMFC}$ was $27.31 \%$. CE is not a kinetic constraint due to this fact these results were relatively low. $\mathrm{CE}$ is not directly linked to power density.

There are many possible reasons for a low range CE for MFCs (0.03-31\%) such as; high Oxygen leakage into the anode chamber (Hao Ren et al., 2014), wastewater consists of heterogeneous complex composition (which including variance electron donors), electron move from substrate to non-electrode electron acceptors presence of sulfate in the solution which decreases electron recovery. MFC internal resistance also affects a decrease in the Coulombic efficiency (Ismail et al., 2017).

\section{Conclusion}

The use of minimum conventional energy sources forces the scholars to think such kind of renewable energy source. We tested the execution of Sediment Microbial Fuel Cell for expanding power by series and hybrid connection. Under present investigation, bioelectricity was successfully generated from sediment via microbial fuel cell innovation. SMFC generate maximum voltage and stable for a long time. With a majority of little units, series configuration can be used to boost up voltage over the level $(1.80 \mathrm{~V})$ required to power the real world electrical or electronic applications; an LED and a dc-motor. This sediment MFC was cost effective and eco-friendly due to utilization of sediment as substrate. Microbial Fuel Cell innovation is still in a beginning period of advancement but shows great promise as new methods for renewable electricity generation. Sediment microbial fuel cells can be utilized as a sustainable power source for remote environmental observing.

\section{Acknowledgments}

The research was supported by Electrical Engineering Department of Motilal Nehru National Institute of Technology (MNNIT), Allahabad, U.P, India.

\section{References}

Abazarian, E., Gheshlaghi, R., Mahdavi, M.A. (2016). The effect of number and configuration of sediment microbial fuel cells on their performance in an open channel architecture, Journal of Power Sources 325,739-744.

Aelterman P., Rabaey K., Pham H. T.(2006).Continuous electricity generation at high voltages and currents using stacked microbial fuel cells, Journal of Environmental Science and Technology, 40(10),3388-3394.

Aelterman, P., Rabaey,K., Pham,H.T., Boon,N. and Verstraete,W. (2006).Continuous electricity generation at high voltages and currents using stacked microbial fuel cells, Environmental Science \& Technology, 40, 3388-3394.

Aller R.C. (1994).The sedimentary Mn cycle in long-island sound - its role as intermediate oxidant and the influence of Bioturbation, $\mathrm{O} 2$, and $\mathrm{C}(\mathrm{Org})$ flux on diagenetic reaction balances,Journal of Marine Research, 52, 259-95.

Ateya B.G., Al-Kharafi F.M. (2002).Anodic oxidation of sulfide ions from chloride brines, Electrochemistry Communications, 4, 231-8.

Bond, D.R., Lovely, D.R. (2003). Electricity production by Geobacter sulfur reducens attached to electrodes, Applied Environmental Microbiology, 69, 1548-1555.

Chaudhuri S.K., Lovely, D.R. (2003). Electricity generation by direct oxidation of glucose in mediatorless microbial fuel cells, Nature Biotechnology, 21, 1229-1232.

Dewan A., Ay S, Karim N, Beyenal H. (2014). Alternative power sources for remote sensors: a review, Journal Power Sources, $245,129-43$.

Donovan C, Dewan A, Heo D, Lewandowski Z, Beyenal H. (2013).Sediment microbial fuel cell powering a submersible ultrasonic receiver: new approach to remote monitoring. Journal Power Sources, 233:79-85.

Donovan C., Dewan A, Heo D, Beyenal H. (2008).Batteryless, wireless sensor powered by a sediment microbial fuel cell, Environmental Science Technology, 42:8591-6. 
Ewing, T., Ha, P.T., Babauta, J.T., Tang, N.T., Heo, D., Beyenal, H. (2014).Scale-up of sediment microbial fuel cells, Journal Power Sources $272,311-319$

Gil G. C.,Chang I S, Kim B.H.(2003). Operational parameters affecting the performance of a mediator-less microbial fuel cell, Journal of Biosensors and Bioelectronics, 18(4):327-334.

Greenman, J.I. and Melhuish, C. (2010).Improved energy output levels from small scale microbial fuel cells, Bioelectrochemistry, 78:44-50.

Greenman, J.I. and Melhuish,C. (2008).Microbial fuel cells based on carbon veilelectrodes: Stack configuration and scalability, International Journal of Energy Research, 32:1228-1240.

Jiang, D., Li, B., Jia, W., Lei, Y. (2010). Effect of inoculum type on bacterial adhesion and power production in microbial fuel cells,Applied Biochemistry and Biotechnology, 160, 182-196.

Kim H. J., Park H. S., Hyun M.S. (2002). A mediator-less microbial fuel cell using a metal reducing bacterium, shewanella putrefaciens, Journal Enzyme and Microbial Technology,30(2), 145-152

Kim H.J., Hyun, M.S., Chang, I.S., Kim, B.H. (1999). A microbial fuel cell type lacase biosensor using a metalreducing bacterium, Shewanella putrefaciens,Journal of Microbiology and Biotechnology, 9, 365-367.

Kreuer, K.D. (2013) Selected Entries from the Encyclopedia of Sustainability Science and Technology, Springer, Fuel Cells, New York

Lemuel B. Wingard, Ching.H. Shaw, James.F. Castne, Bioelectrochemical fuel cells, Journal Enzyme and Microbial Technology, Volume 4,1982,137-142.

Liu, H., Ramnarayanan, R., and Logan, B. E.(2004). Production of electricity during wastewater treatment using a single chamber microbial fuel cell,Environmental Science \& Technology, 38:2281-2285.

Majumder, D., Maity, J.P., Chen, C.Y., Chen, C.C., Yang, T.C., Chang, Y.F., Hsu, D.W. and Chen, H.R. (2014). Electricity generation with a sediment microbial fuel cell equipped with an air-cathode system using photo bacterium, International journal of Hydrogen Energy 39, 21215-21222.

Oh, S.E., Logan, B.E.(2007).Voltage reversal during microbial fuel cell stack operation,Journal of Power Sources , 167 : 1117.

Panwar, N.L, Kaushik, S.C., Kothari,S. (2011). Role of renewable energy sources in environmental protection: a review, Renewable \& Sustainable Energy Reviews, 15, 15131524.

Reimers C.E., Girguis P, Stecher HA, Tender LM, Ryckelynck N, Whaling P. (2006).Microbial fuel cell energy from an ocean cold seep, Geobiology, 4, 123-36.

Reimers C.E., Tender L M, Fertig S.(2001). Harvesting energy from the marine sediment-water interface,Journal Environmental Science \& Technology, 35(1), 192-195.
Reimers, C.E., Tender L.M., Fertig, S. and Wang, W. (2001) Harvesting Energy from the Marine Sediment-Water Interface,Journal, Environmental Sciences and Technology, 35(1), 192-195.

Ren, H., Torres,C., Parameswaran, P., Rittmann, B.E. and Chae, J. (2014). Improved current and power density with a microscale microbial fuel cell due to a small characteristic length, Biosensors and Bioelectronics, 61, 587-592588

Rismani-Yazdi H., Christy, A.D., Dehority, B.A., Morrison, M., Yu, Z., Tuovinen, O.H. (2007).Electricity generation from cellulose by rumen microorganisms in microbial fuel cells, Biotechnology and Bioengineering, 97, 1398-1407.

Tender L.M., Gray S.A., Groveman E., Lowy D.A., Kauffman P., Melhado J., et al. (2008). The first demonstration of a microbial fuel cell as a viable power supply: powering a meteorological buoy, Journal Power Sources, 179:571-5.

Wang, D.B., Song, T.S., Guo, T., Zeng, Q., Xie, J. (2014). Electricity generation from sediment microbial fuel cells with algae-assisted cathodes, International Journal Hydrogen Energy, 39, 13224-13230.

Wotawa-Bergen, A.Q., Chadwick, D.B., Richter, K.E., Tender, L.M., Reimers, C.E. and Gong, Y. (2010). Operational testing of sediment microbial fuel cells in San Diego Bay,OCEAN, MTS/IEEE SEATTLE, Seattle, WA, 2010, pp. 1-6.

Xu, X., Zhao, O., Wu, M., Ding, J., Zhang,W. (2017). Biodegradation of organic matter and anodic microbial communities analysis in sediment microbial fuel cells with/without Fe(III) oxide addition, Bioresource Technology $225,402-408$

Zainab Z. Ismail and Ali A. Habeeb (2017).Experimental and modeling study of simultaneous power generation and pharmaceutical wastewater treatment in microbial fuel cell based on mobilized biofilm bearers, Renewable Energy, 101, 1256-1265

Zhang G., Zhao, Q., Jiao, Y., Wang, K., Lee, D.J., Ren, N. (2012). Efficient electricity generation from sewage sludge using bio cathode microbial fuel cell, Water Research,46, 43-52.

Zhang, H., Zhu,D., Song,T.S. Ouyang, P. and Xie, J.(2015). Effects of the presence of sheet iron in fresh water sediment on the performance of a sediment microbial fuel cell, international journal of hydrogen energy 40,16566 -1657.

Zhou, Y.-L., Yang, Y., Chen, M., Zhao, Z.-W., Jiang, H.L.(2014). To improve the performance of sediment microbial fuel cell through amending colloidal iron oxyhydroxide into freshwater sediments, Bioresource Technology 159, 232-239. 